\title{
worldview
}

- -

\section{THE REVOLUTION IN AFRICA}

Christianity and Crisis, the distinguished biweekly journal founded by Reinhold Niebuhr and John C. Bennett, is currently marking its twentieth anniversary, and as part of its anniversary, observance it has published a special double issue on Africa. We would commend this issue to Worldview's readers.

"As much as we have considered the question of freedom and self-determination for all peoples since the end of World War II," the editors remark in their introduction, "it is clear that we have not prepared, and perhaps could not have been prepared, for what has happened in Africa. during recent months. We are called upon to make great readiustments in our thinking and in our policy-to come to grips with a world that hardly seemed to exist yesterday. Unquestionably we are involved in the new world, but there is much understandable confusion regarding our role in it."

Several sources of our confusion are made clear in this issue of Christianity and Crisis by Robert C. Good, who was coordinator of President Kennedy's task force on Africa. Writing on "The Danger of Disillusionment with Africa," Mr. Good observes that, "paradoxically, our trouble arises partly from our fine anti-colonial and liberal traditions. It was not very long ago that we placed unquestioning faith in those touchstones of the new age, self-determination and collective security ... We no longer suffer the illusions of liberal international political theory. But we are only beginning to realize that, far from a solution to the problems of disorder and far from a guarantor of amicable relations, the era of independence-foreveryone simply reshapes the frame within which the persistent problems of politics must be viewed."

The challenge which the revolution in Africa offers to Americans is thus a challenge to their political maturity-to their ability to come to terms, realistically, with problems new to their experience. Much of what has happened (and will happen) in Africa is an affront both to the civil- ized values and the democratic presuppositions of the West. But if, for these reasons, the new African nations are simply despaired of and written off as lost to decency and to freedom, the Western nations will have succumbed to a tragic simplism and irresponsibility.

The new administration in Washington, fortunately, offers hope that it will meet the African challenges more creatively than this nation has met them in the past. In his inaugural address President Kennedy, speaking of the new nations, declared that "we shall not always expect to find them supporting our views;" but, he added, we "always hope to find them supporting their own freedom."

This declaration should become the keystone of the nation's policy. The new nations hate any suggestion of colonialism much more passionately than they love "freedom" as the West conceives it. They have no wish to choose sides, or to become pawns, in the Cold War. The best of their leaders are concerned for the speedy development of their states as independent, viable political and economic units. It is toward this that the United States must assist them - through expanded programs of economic and technical assistance, through understanding of their aspirations for independence. And we must do this with generosity, with patience and with tact.

Editor's Note: In its December 1958 issue Worldview inaugurated a series of essays on the moral implications of nuclear warfare. The series was concluded in the issue of October 1960. The Church Peace Union has now published this series in a seventy-eight page pamphlet, under the title The Monal Dilemma of Nuclear Weapons. Copies of the pamphlet may be ordered from The Church Peace Union, 170 East 64th Street, New York 21, New York. The price is one dollar for a single copy. Bulk prices are available upon request. 